\title{
Pengabaian Suku Asli dalam Proses Perdamaian di Kolombia
}

\author{
Farhan Helmi Siregar \\ 2015330010
}

\author{
Mahasiswa Ilmu Hubungan Internasional, Fakultas Ilmu Sosial dan Ilmu Politik \\ Universitas Katolik Parahyangan
}

\begin{abstract}
Peace talks between the Goverment of Republic of Colombia with Fuerzas Armadas Revolucionarias de Colombia-Ejército del Pueblo (FARC-EP) started from 2011 to 2016, and followed by disarmament and transition phase until 2017. The talks and process have resulted peace agreement between the conflicting sides in 2016, FARC-EP disarmament process, and transitioning the rebels into civilians' life. Considered as a success by some observers, the peace process is not yet solving the problem about indigenous people affected by an half-century conflict between the goverment and FARC-EP. This paper will examine discourses from perspective of community security which is originated from the concept of human security that involves violent action, and other threats towards indigenous people in Colombia, the Awa, and Wounaan People between 2011 to 2017. The goal of discursive practices on violent action towards indigenous "people during the peace process in Colombia is to explain the threat to community security in Colombia due to the problem occured in indigenous community.
\end{abstract}

Keywords: Colombia, FARC-EP, Wounaan, Awa, Colombia Peace Process, Violence, Community Security.

\section{Pendahuluan}

Pada tahun 1964, Fuerzas Armadas Revolucionarias de Colombia-Ejercito del Pueblo (FARC-EP) terbentuk saat masa represi Pemerintah Kolombia terhadap gerakan komunisme. Sejak saat itulah, FARC-EP menjadi salah satu aktor utama yang menjadi penggerak konflik sipil yang berkepanjangan di Kolombia. Aksi kekerasan terhadap warga, penculikan, hingga pembunuhan pejabat pemerintah menjadi hal yang biasa dilancarkan oleh FARC-EP. Tahun 2010-an menjadi momen puncak melemahnya FARC-EP, setelah banyak petinggi mereka yang terbunuh serta berkurangnya wilayah kekuasaan, membuat Presiden Kolombia saat itu, Juan Manuel Santos memanfaatkan momentum tersebut untuk mengadakan negosiasi

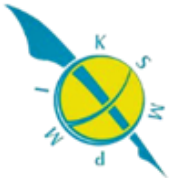


perdamaian dengan FARC-EP. Proses perdamaian berhasil dilakukan oleh Presiden Santos setelah menempuh proses negosiasi dan ratifikasi yang panjang perjanjian perdamaian oleh parlemen pada tahun 2016. Masyarakat Kolombia di daerah konflik tersebut akhirnya mendapatkan hak mereka kembali, namun apakah seluruh masyarakat di wilayah konflik benar-benar mendapatkan haknya?

Pemenuhan hak bagi masyarakat suku-suku asli di Kolombia masih belum sebagaimana mestinya, dibuktikan dengan banyaknya aksi kekerasan dan pengusiran terhadap suku asli. Perjanjian damai antara pemerintah dengan FARCEP sebenarnya sudah membahas solusi permasalahan warga pedalaman dan realisasi pemenuhan hak korban konflik. Namun, keterlibatan suku-suku asli dalam pembuatan perjanjian tersebut ternyata kurang maksimal, dimana hal tersebut membuat perjanjian tersebut kurang menguntungkan bagi mereka, masalah tersebut menjadi fokus pembahasan dan memunculkan research question yaitu perihal Bagaimana pengaruh kurang dilibatkannya suku-suku asli dalam proses perdamaian di Kolombia terhadap pemenuhan hak mereka sebagai warga negara? Dengan menggunakan pendekatan community security dan menggunakan post-kolonialisme sebagai dasar teori, jawaban dari research question tersebut adalah bahwa keamanan komunitas suku-suku asli masih terancam akibat kurang dilibatkan dan diperhatikannya mereka dalam proses perdamaian di Kolombia.

\section{Kerangka Teori}

Dasar teori untuk menganalisis fenomena adalah post-kolonialisme. bagian ini menjelaskan mengenai pemikiran ahli post-kolonialisme yang digunakan serta argumen utamanya, dan alasan pemilihan post-kolonialisme sebagai dasar teori. Secara garis besar, post-kolonialisme memiliki fokus untuk menganalisis kondisi pihak terjajah yang diposisikan sebagai pihak tereksploitasi dan tertekan secara historis ${ }^{1}$. Argumen utama dari post-kolonialisme berasal dari Edward Said, seorang

\footnotetext{
${ }^{1}$ Pramod K. Nayar, The Postcolonial Studies Dictionary (Chichester: Wiley Blackwell,
} 2015), 122. 
profesor di Universitas Columbia dan dianggap sebagai salah satu pencetus postkolonialisme. Post-kolonialisme Edward Said didasarkan pada pencitraan oleh pihak occident atau Barat yang salah mengenai orient atau Timur, di mana pihak Timur selalu dicitrakan sebagai kaum tidak beradab atau primitif. ${ }^{2}$ Konsep orientalisme menurut Said memiliki dasar dari pembedaan Timur dengan Barat, dan konsep ini biasa menjadi justifikasi bagi segala bentuk aksi kolonialisme oleh negara-negara di Eropa, perang sipil, dan bentuk pertumpahan darah lainnya sebagai akibat dari kolonialisme barat. ${ }^{3}$ Pihak kolonial yang lebih kuat menyuntikan kebudayaan mereka di negara yang diduduki yang bertujuan untuk membuat kultur asli negara terjajah menjadi terabaikan. ${ }^{4}$

Teori post-kolonialisme dipilih sebagai dasar teori karena memiliki kesesuaian dengan fenomena yang menjadi topik penulisan yaitu analisis mengenai pihak yang terpinggirkan dan tertindas, dimana pihak tersebut menjadi orient dalam post-kolonialisme Edward Said. Menurut penulis, unit analisis dari postkolonialisme sesuai dengan apa yang ingin dianalisis, yaitu berada pada tingkatan negara, dan tulisan ini menganalisis apa yang terjadi dalam sebuah negara. Sesuai dengan unit analisis yang hanya berfokus di suatu negara, indikator yang menjadi tujuan ialah kekerasan terhadap suku asli yang menurut Edward Said disebabkan diskriminasi dan pengabaian.

\section{Konsep Community Security dalam Human Security}

Melindungi keberagaman kultur merupakan salah satu fokus dari human security, karena menurut UNESCO, apabila keberagaman tidak dipertahankan, maka marginalisasi terhadap suatu kelompok dengan budaya berbeda akan terjadi. ${ }^{5}$ Alasan tersebut menjelaskan pentingnya salah satu dimensi dari human security

2 Lutfi Hamadi, "Edward Said: The Postcolonial Theory And The Literature of Decolonialization", European Scientific Journal 2, Edisi spesial (2014): 40.

${ }^{3}$ Ibid

${ }^{4}$ Ibid.

5 United Nations Educational, Scientific and Cultural Organization , Human Security Approaches and Challenges, 2008, Paris, 24. 
yang melindungi keberagaman, yaitu community security. Sebagai salah satu dari dimensi dari human security, community security membentuk kapasitas dan keinginan negara serta sebuah komunitas untuk menyampaikan permasalahan yang dihadapi melalui kebijakan di tingkat nasional. ${ }^{6}$ Seperti beberapa dimensi dari human security, konsep community security juga berbasis people-centered dan berorientasi untuk mencegah dan bersifat komprehensif. Berdasarkan pengertian tersebut, hubungan antar negara dengan komunitas tertentu menjadi salah satu faktor bagi tercapainya community security. Selain itu, community security memiliki beberapa pendekatan dalam penerapannya, yaitu kooperatif, forward thinking, menyempurnakan mekanisme keamanan yang ada, sensitif terhadap konflik dan isu gender, dan bekerja di berbagai level. ${ }^{7}$ Kemudian permasalahan yang dijadikan fokus dari konsep ini biasanya berupa diskriminasi terhadap etnis tertentu, pencegahan konflik antar etnis, dan perlindungan terhadap suku-suku asli. ${ }^{8}$

Aspek perlindungan suku asli dalam dimensi community security adalah fokus dari pembahasan dalam tulisan ini. Dalam Human Development Report tahun 1994, dinyatakan bahwa suku tradisonal banyak mengalami diskriminasi dari berbagai pihak dan diperparah dengan tensi tinggi antar etnis. ${ }^{9}$ Kemudian, pada tahun 1993, United Nations menandai tahun 1993 sebagai tahun bagi penduduk atau suku asli untuk menyadarkan nasib suku asli yang masih dibawah ancaman. ${ }^{10}$ Beberapa bentuk ancaman terhadap suku atau penduduk asli biasanya berupa kekerasan, pengusiran, dan penghilangan kebebasan berekspresi sering dilakukan oleh otoritas negara. Hal tersebut memperlihatkan bahwa perlindungan terhadap suku asli sangat relevan terhadap topik pembahasan karena suku-suku asli di Kolombia masih mendapatkan kekerasan dan kehilangan tempat tinggal hingga saat

\footnotetext{
${ }^{6}$ Will Bennet, Community Security Handbook (London: Saferworld, 2014), 4.

${ }^{7}$ Ibid, hal. 7.

8 Global Development Research Center, Human Security: Seven Categories, https://www.gdrc.org/sustdev/husec/z-categories.html (diakses pada November 24, 2017).

${ }^{9}$ United Nations Development Programme, Human Development Report 1994, 1994, New York, 32.

${ }^{10}$ Ibid.
} 
ini. Kemudian secara garis besar, konsep community security merupakan sebuah konsep yang mampu memberikan solusi bagi nasib suku asli, karena bersifat people-centered dan meningkatkan keinginan pemerintah untuk mengetahui permasalahan, yang membuat suku-suku asli mampu menyampaikan masalah secara langsung ke pemerintah untuk kemudian dibuatkan kebijakan sesuai dengan masalah yang dialami jika berjalan ideal.

\section{Sejarah suku Awa dan Wounaan Di Kolombia}

Kolombia memiliki banyak suku-suku asli di daerahnya, di mana $4 \%$ dari populasi di Kolombia adalah masyarakat suku asli. ${ }^{11}$ Bagian ini akan membahas mengenai asal muasal, dan gaya hidup dari dua suku asli di Kolombia yang menjadi pembahasan dalam tulisan ini, yaitu suku Awa dan Wounaan. Suku Awa masih keturunan peradaban Meso-Amerika, yaitu peradaban Tumaco yang memiliki hubungan budaya dengan peradaban Maya dan Aztec. Pada masa pendudukan Kerajaan Spanyol, penduduk suku Awa menjadi buruh untuk membangun jalan kearah tempat ditemukannya emas di dekat sungai. Pada mulanya, suku Awa merupakan suku hunter-gatherer. Namun seiring perkembangan zaman, mereka bertani dan beternak. Saat ini, suku Awa bermukim di daerah departemen Narino yang berada di barat daya wilayah Kolombia. ${ }^{12}$

Selanjutnya akan dijelaskan mengenai suku terakhir yaitu suku Wounaan yang memiliki kemiripan dengan suku Embera. Suku Wounaan tersebar dari Panama sampai ke Kolombia. Di Panama mereka menepati daerah Darien, sementara di Kolombia mereka bermukim di Departemen Choco. ${ }^{13}$ Menurut data pemerintah Kolombia pada tahun 2005, populasi dari suku Wounaan berjumlah 9.006 orang dan mayoritas bermukim di Departemen Choco yang terletak di sebelah

11 International Work Group for Indigenous Affairs, Indigenous peoples in Colombia, https://www.iwgia.org/en/colombia (diakses pada November 27, 2017).

12 BBC News, The Awa: Colombia's Tribal People, BBC News, Agustus 27, 2009, http://news.bbc.co.uk/2/hi/americas/8224593.stm (diakses pada November 27, 2017).

${ }^{13}$ Native Planet, The Embera and Waounan Indigenous People of Panama and Colombia, http://www.nativeplanet.org/indigenous/embera/ (diakses pada November 27, 2017).

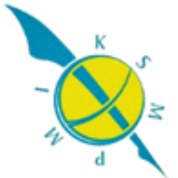


barat Kolombia. ${ }^{14}$ Hampir serupa dengan suku Awa, suku Wounaan berburu dan menangkap ikan untuk mencari makan. Saat ini mereka bekerja sebagai penyadap getah karet dan penebang pohon untuk memenuhi kebutuhan ekonomi. ${ }^{15}$ Setelah melihat penjelesan mengenai suku Awa dan Wounaan, dapat disimpulkan bahwa mereka tidak hanya berada di Kolombia. Mereka tersebar di negara Amerika Latin lainnya dan pola hidupnya berkembang seiring dengan arus zaman. Hal ini terjadi sejak datangnya Kerajaan Spanyol ke tanah Amerika hingga tuntutan dari aspek ekonomi.

\section{Perjalanan Proses Perdamaian Pemerintah Kolombia - FARC-EP}

Peristiwa pertama yang mengawali pembicaraan antara kedua pihak adalah pembicaraan yang dilakukan pada Bulan Maret sampai Oktober 2011 di Kolombia dan Venezuela. Pembicaraan ini merupakan persiapan dari proses-proses negosiasi selanjutnya, yang memutuskan Kuba dan Norwegia menjadi penjamin dari proses perdamaian antara Kolombia dan FARC-EP. Kemudian dilanjutkan oleh pertemuan tertutup antara Kolombia dan FARC-EP di Kuba pada Agustus 2012. Pertemuan tertutup ini bertujuan membuat susunan persetujuan sebagai panduan dalam proses negosiasi ${ }^{16}$. Susunan yang akan menjadi fokus pembicaraan adalah kebijakan agraria dan pembangunan desa, partisipasi politik FARC-EP, penghentian konflik bersenjata dan proses demobilisasi, perdagangan narkotik ilegal, ganti rugi korban konflik, dan implementasi dari persetujuan yang telah dinegosiasikan. Setelah hasil pertemuan tersebut dipublikasikan, Presiden Juan Manuel Santos mengumumkan pembicaraan resmi akan diadakan di Norwegia pada Bulan Oktober 2012 dan selanjutnya di Kuba. Topik dalam susunan pembicaraan damai yang pertama yaitu mengenai kebijakan agrarian dan pembangunan pedesaan mencapai kata sepakat

\footnotetext{
${ }^{14}$ Amnesty International, Wounaan Indigenous Community in Danger, 2017, London, 2.

15 Encylopedia.com, Embera and Wounaan, http://www.encyclopedia.com/humanities/encyclopedias-almanacs-transcripts-and-maps/embera-and-wounaan (diakses pada November 27, 2017).

${ }^{16}$ June S. Beittel, Peace Talks in Colombia, ( Washington D.C. : Congressional Research Service, 2015), 15.
}

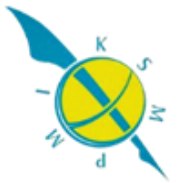


pada Bulan Mei 2013. Sehingga pemerintah meredistribusi lahan ternak dan memformalkan kepemilikan tanah sebagai hasil dari kesepakatan tersebut. ${ }^{17}$ Pada topik pembicaraan kedua di bulan November 2013 berbicara mengenai peran politik FARC-EP di Kolombia. Kesepakatan dalam pembicaraan tersebut membuat pemerintah memudahkan partisipasi pihak oposisi, termasuk FARC-EP, serta memudahkan akses terhadap media dan proses pembentukan partai politik. ${ }^{18}$ Sementara pada kesepakatan topik ketiga, perdagangan narkoba ilegal baru tercapai di bulan Mei 2014 dengan poin-poin utamanya adalah pembasmian ladang koka, pengaturan kesehatan umum dan konsumsi obat-obatan, serta solusi terhadap produksi narkoba dan penyelundupannya. Pada sesi akhir pembicaraan proses damai di tahun 2015, tercapai dua kesepakatan yang utama. Kesepakatan pertama adalah FARC-EP tidak lagi merekrut tentara anak di bawah usia 17 tahun. Kesepakatan selanjutnya ialah pembersihan ladang ranjau yang dilakukan oleh kedua pihak. Setelah mendapat persetujuan dengan pihak FARC-EP, hambatan muncul akibat adanya penolakan dari pihak oposis di parlemen yang mengharuskan adanya revisi perjanjian perdamaian agar kemudian dapat diratifikasi oleh parlemen pada tanggal 1 Desember $2016 .{ }^{19}$

\section{Diskriminasi Terhadap Suku Awa dan Wounaan Saat Proses Perdamaian}

Menjelang diadakannya referendum untuk menyetujui perjanjian perdamaian dengan FARC-EP, masyarakat suku asli Kolombia mayoritas mendukung adanya perjanjian perdamaian dikarenakan mereka sering menjadi korban dari konflik pemerintah dengan FARC-EP. Masyarakat suku asli Kolombia juga sering terjebak dalam baku tembak antara tentara dan polisi dengan

\footnotetext{
${ }^{17}$ Ibid, hal. 19.

${ }^{18}$ Ibid, hal. 21.

19 The Guardian, Colombia's government formally ratifies revised Farc peace deal, The Guardian, Desember, 1, 2016, https://www.theguardian.com/world/2016/dec/01/colombiasgovernment-formally-ratifies-revised-farc-peace-deal (diakses pada November 29, 2017).
}

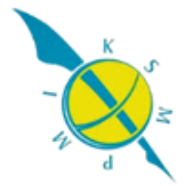


pemberontak FARC-EP. Selain itu, mereka sering dipaksa untuk bergabung dalam pergerakan pemberontak. Setelah menjadi pihak yang paling menderita akibat konflik selama setengah abad, kelompok suku-suku asli ternyata tidak dilibatkan secara aktif oleh pihak pemangku kepentingan dalam perumusan perjanjian perdamaian dengan FARC-EP di mana suara mereka didengarkan hanya pada urusan mengenai hak teritorial saja. Hal tersebut kemudian mengakibatkan proses perdamaian di Kolombia tidak dapat menjamin hak mereka, seperti yang akan dibahas pada bagian mengenai diskriminasi terhadap Suku Awa dan Wounaan.

Suku yang didiskriminasi akibat konflik adalah Suku Awa yang mayoritas menempati Departemen Narino. Tahun 2013, saat terjadinya operasi militer melawan pemberontak, sebanyak 44 keluarga mengalami pengusiran paksa dan terjadi pembunuhan terhadap dua anggota suku Awa. ${ }^{20}$ Situasi tersebut kemudian membuat anggota Suku Awa hidup dalam ketakutan dan ketidakpastian. Bahkan saat ini, kehidupan mereka masih terancam. Terbukti dengan terbunuhnya dua orang Suku Wounaan pada bulan April tahun ini. ${ }^{21}$ Pengusiran paksa merupakan kasus diskriminasi yang sering dialami oleh suku asli Kolombia, salah satunya Awa. Menurut data tahun 2016, 70\% penduduk Kolombia yang terusir dari tempat tinggalnya adalah masyarakat suku asli. ${ }^{22}$ Hal ini seakan mengamini pernyataan yang tertera pada Human Development Report tahun 1994 bahwa suku asli masih berada dibawah ancaman, bahkan hingga saat ini.

Bentuk diskriminasi yang mereka alami serupa dengan Suku Awa, yakni pengusiran dan terjebak baku tembak. Setelah FARC-EP meninggalkan kebun koka

\footnotetext{
${ }^{20}$ Washington Office on Latin America, Rights of Colombian Indigenous Groups under Threat, https://www.wola.org/analysis/rights-of-colombian-indigenous-groups-under-threat/ (diakses pada November, 29, 2017).

${ }^{21}$ Amnesty International, Colombia: Wave of killings of Indigenous people highlights shortcomings in implementation of peace process, https://www.amnesty.orglen/latest/news/2017/04/colombia-ola-de-asesinatos-de-indigenas-resalta-fallas-deimplementacion-del-proceso-de-paz/ (diakses pada November, 29, 2017).

${ }^{22}$ Norwegian Refugee Council, New wave of violence threatens Colombia's peace prospects, https://www.nrc.no/news/2017/august/new-wave-of-violence-threatens-colombias-peaceprospects/ (diakses pada November, 29, 2017).
} 
dan tambang ilegal, pemberontak lain memperebutkan tempatnya. Hal mengakibatkan 500 orang Wounaan terusir di Departemen Choco pada Maret 2017. ${ }^{23}$ Pengusiran seperti ini bukan pertama kali terjadi pada tahun ini. Dua pengusiran sudah terjadi sebelumnya, yaitu di Santa Rosa de Guayacan dan Chagpien Tordo. Selain pengusiran, Suku Wounaan juga terjebak dalam baku tembak antar pemberontak atau antara pemberontak dengan pasukan pemerintah. Pada Juli tahun ini, seorang anak menjadi korban ranjau darat yang ditaruh oleh pemberontak. ${ }^{24}$

Pemerintah Kolombia sudah menyertakan sebuah program bernama Comprehensive Rural Reform untuk menjamin nasib masyarakat pedalaman lebih baik setelah konflik $^{25}$. Program ini fokus pada komunitas dan etnis di pedalaman dan mempromosikan partisipasi masyarakat dalam pembuatan regulasi. Namun, dalam program tersebut tidak terdapat pasal spesifik yang membahas mengenai suku-suku asli di Kolombia. Hal tersebut dimungkinkan terjadi karena pada saat pembuatan keputusan, pemerintah tidak terlalu mendengarkan suara dari suku-suku asli. Jika dikaitkan dengan dasar teori dan indikatornya, kejadian ini membuktikan bahwa Suku Awa dan Wounaan mengalami 'kekerasan' dalam berbagai bentuk akibat diskriminasi dalam hal penjaminan hak mereka. Hal itu diperparah dengan pengabaian oleh pemerintah yang dibuktikan dengan tidak dilibatkannya suku asli Kolombia secara aktif dalam perjanjian perdamaian dengan FARC-EP sehingga mengakibatkan hak mereka tidak terpenuhi. Mengacu pada teori post-kolonialisme Edward Said, Suku Awa dan Wounaan merupakan pihak orient karena merupakan pihak yang diabaikan dan mengalami diskriminasi, serta pemaksaan dalam bentuk perjanjian tanpa keterlibatan mereka.

23 ABColombia, Chocó: Indigenous people forced to flee, https://www.abcolombia.org.uk/choco-indigenous-people-forced-to-flee/ (diakses pada November, 29, 2017).

${ }^{24}$ Amnesty International, Wounaan Indigenous Community in Danger, 2017, London, 1.

${ }_{25}$ Presidencia De La Republica, Summary of Colombia's Agreement to End Conflict and Build Peace, 2016, Bogota.

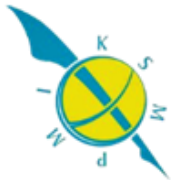




\section{Kesimpulan}

Tulisan ini menjelaskan bagaimana suku asli di Kolombia masih terancam akibat tidak dilibatkan dalam proses dan perjanjian perdamaian. Dengan pemikiran post-kolonialisme Edward Said sebagai dasar teori memperlihatkan bahwa suku asli menjadi pihak orient yang selalu mengalami diskriminasi. Analisis mengenai fenomena yang dibahas dalam tulisan ini menekankan pada pentingnya melibatkan seluruh elemen masyarakat dalam pengambilan keputusan sebuah negara. Rekomendasi untuk mengatasi permasalahan diskriminasi terhadap suku asli adalah dengan merevisi perjanjian perdamaian yang dapat memenuhi keinginan suku asli karena mereka merupakan pihak yang paling rentan mengalami dampak konflik secara langsung.

\section{Daftar Pustaka}

ABColombia, Chocó: Indigenous people forced to flee,

https://www.abcolombia.org.uk/choco-indigenous-people-forced-to-flee/ (diakses pada November, 29, 2017)

Amnesty International, Colombia: Wave of killings of Indigenous people highlights shortcomings in implementation of peace process, https://www.amnesty.org/en/latest/news/2017/04/colombia-ola-de-asesinatos-deindigenas-resalta-fallas-de-implementacion-del-proceso-de-paz/ (diakses pada November, 29, 2017)

Amnesty International, Wounaan Indigenous Community in Danger, 2017, London.

BBC News, The Awa: Colombia's Tribal People, BBC News, Agustus 27, 2009, http://news.bbc.co.uk/2/hi/americas/8224593.stm (diakses pada November 27, 2017)

Beittel, June.S. Peace Talks in Colombia. Washington D.C. , Congressional Research Service, 2015.

Bennet, Will. Community Security Handbook. London, Saferworld, 2014.

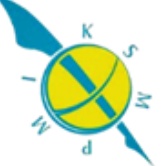


Encylopedia.com, Embera and Wounaan, http://www.encyclopedia.com/humanities/encyclopedias-almanacs-transcriptsand-maps/embera-and-wounaan (diakses pada November 27, 2017).

Global Development Research Center, Human Security: Seven Categories, https://www.gdrc.org/sustdev/husec/z-categories.html (diakses pada November 24, 2017).

The Guardian, Colombia's government formally ratifies revised Farc peace deal, The Guardian, Desember, 1, 2016, https://www.theguardian.com/world/2016/dec/01/colombias-governmentformally-ratifies-revised-farc-peace-deal (diakses pada November 29, 2017).

Hamadi, Lutfi. "Edward Said: The Postcolonial Theory And The Literature of Decolonialization”, European Scientific Journal 2, Edisi spesial (2014): 39-46. International Work Group for Indigenous Affairs, Indigenous peoples in Colombia, https://www.iwgia.org/en/colombia (diakses pada November 27, 2017).

Native Planet, The Embera and Waounan Indigenous People of Panama and Colombia, http://www.nativeplanet.org/indigenous/embera/ (diakses pada November 27, 2017).

Nayar, Pramod K. The Postcolonial Studies Dictionary. Chichester, Wiley Blackwell, 2015.

Norwegian Refugee Council, New wave of violence threatens Colombia's peace prospects, https://www.nrc.no/news/2017/august/new-wave-of-violencethreatens-colombias-peace-prospects/ ( diakses pada November, 29, 2017).

Presidencia De La Republica, Summary of Colombia's Agreement to End Conflict and Build Peace, 2016, Bogota.

United Nations Development Programme, Human Development Report 1994, 1994, New York.

United Nations Educational, Scientific and Cultural Organization, Human Security Approaches and Challenges, 2008, Paris.

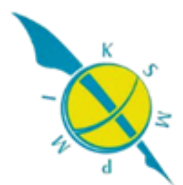


ISSN 0216-5031

$\mathrm{H}$ a I a m a n | 36

Washington Office on Latin America, Rights of Colombian Indigenous Groups under Threat, https://www.wola.org/analysis/rights-of-colombian-indigenousgroups-under-threat/ ( diakses pada November, 29, 2017). 